\title{
What Bleriot could never have
}

\section{known}

Air travel today, it has to be said, is fairly common place. As common place perhaps as modern dentistry. So I recently mused in the periods between announcements about gate numbers and boarding times, demonstrations of how to buckle (and unbuckle) a seat belt and entreaties to purchase duty free this or tax reduced that.

Not that I am suggesting for a moment that either air travel or dentistry are any the less remarkable in their progress or in the service they provide for being as it were, taken for granted as features of a familiar world around us. Indeed both are remarkable. For example, I could no more have attended the International Association for Dental Research Conference in Brisbane last month, nor enjoyed a great skiing holiday in Beaver Creek, Colorado earlier in the year without the intercontinental penetration made possible by the jet engine. And I am demonstrably not alone in that. Many of us are immanently taking off for long weekends, weeks, maybe months to hitherto unexplored nooks or favourite places of the world. Similarly though, many people could not now be enjoying the benefits of, say, successful implants or excellent aesthetic smiles were it not for the technical and scientific advances in our profession.

Of course what Louis Bleriot could never have known when he triumphantly became the first person to fly across the English Channel in July 1909 was the complexity that his apparently simple, if momentous, enterprise would subsequently spawn. How horrified might he be with the shenanigans over the number and size of carry-on bags, the weight (or overweight) of luggage, how well the meals are served, how check-in procedures are compared with other airlines?

Intriguingly, at a similar stage of the early 1900s when Bleriot was planning and making his uninterrupted flight, which unintentionally also has the connotation of an airborne period blissfully unpunctuated by pronouncements about customs procedures, immigration controls and quarantine requirements, a man of dentistry was involved in similarly groundbreaking work. Dr Willoughby Dayton Miller published what he called his 'chemico-parasitic' theory of the development of tooth decay. It was a beginning which history has traced as the start of our understanding of the aetiology, subsequently treatment of, and more latterly prevention of the process of dental caries.

Both endeavours, arguably straightforward in themselves with the benefit of hindsight, were therefore to give rise to complexities far beyond the enviable vision of even these two men, Bleriot a French aviator and Miller an American dentist originally from Ohio but latterly settled in Germany. How fascinating to speculate that they might have unknowingly passed on some ndon. How equally tantalising to wonder whose paths might be crossing now, deep in thought or earnest activity, in the equivalent years of this century in the process of making changes that will radically shape our lives hereafter.

So what should we make of this complex simplicity? Given that we, and our patients, do take so very much for granted, because we can, how should we use the pause for reflection that air travel, and holidays and leisure time provide to help us make things better still? The extraordinary business and activity that we have created by our industry, by which I mean our ability to be busy in problem solving not in a tendency to become industrialised, has benefited millions of people by improving their oral health and consequently their quality of life. What Miller could not have foreseen was the plethora of treatment modes, variable techniques, pieces of equipment, materials, epidemiological surveys, styles of dental care service provision, methods of remuneration and types of approach to which his theory would lead one hundred or so years on.

It is salient to reflect on such stealthy and valuable progress as many of us enter a summer holiday season, not to gloat on how wonderful we are but to ponder on how much better we can become. A process of which both Bleriot and Miller in their own inimitable ways would have doubtless approved. Seats for take off please.

Stephen Hancocks OBE, Editor in Chief doi: 10.1038/sj.bdj.4813876 